\title{
ANALYSIS OF INTENTION TO USE TRANSJAKARTA BUS
}

\author{
Naufal Arief Rahadianto \\ Faculty of Management and Business \\ Bogor Agricultural University, Indonesia \\ E-mail: naufalrahadianto@yahoo.com \\ Syamsul Maarif \\ Faculty of Management and Business \\ Bogor Agricultural University, Indonesia \\ E-mail: syamsul4958@gmail.com \\ Lilik Noor Yuliaty \\ Faculty of Human Ecology \\ Bogor Agricultural University, Indonesia \\ E-mail: lilikny@apps.ipb.ac.id \\ Submission: $19 / 10 / 2017$ \\ Revision: 03/06/2018 \\ Accept: 01/01/2019
}

\section{ABSTRACT}

Congestion is a common problem in big cities, including Jakarta as a capital of Indonesia. Increasing the number of vehicles in Jakarta is not proportional to the growth of roads. This makes the road become inconducive. The use of public transportation is a solution to solve this problem. While public intention in using public transportation is still considered low. Research on the intention of using public transport is still less. Based on this, further research is needed that focuses on the intention to use public transportation. This study explores the intention to use public transport that focus on Transjakarta busway while considering several factors in Jakarta, Indonesia. This study describe intention behavior of Transjakarta potential user, study and explores the relationship between intention to use Transjakarta and other latent factors, including personal norms, social influence, environment impact, and perceived quality. The empirical data were drawn from 190 potential users of Transjakarta in Jabodetabek that still use private vehicle, car or motorbike in daily activity using questionnaire method. Structural equation model (SEM) technique is used to analyze the conceptualized relationship model. The result reveal that personal norms, social influence, and perceived quality significantly affect potential users' intention behavior. From the empirical result, managerial implications were discussed.

Keywords: intention behavior, transportation, Transjakarta, personal norms, social influence, environment impact, perceived quality 


\section{INTRODUCTION}

Increasing the use of private vehicles in urban areas in developing countries has been increased to environmental problems such as congestion and air pollution. Similar to Jakarta area which is as the center of government and business with a population of 10.08 million people, Jakarta has a high level of traffic problems. Population movement occurs so quite busy, both within the Jakarta area, which entered Jakarta, as well as out of Jakarta

According to Polda Metro Jaya Ditlantas more than 17 million vehicles are distributed in Jakarta in 2014 year. Based on data of Department of Transportation Jakarta, every year the total number of vehicles in Jakarta is increased until $9 \%$. Every day there are about 1235 motorcycles and 835 new cars come to the street. Unfortunately, the number of additional vehicles is not balanced with the additional of roadways that only $0.1 \%$ increasing from the total of of $48,502,763.16 \mathrm{~m}^{2}$ road area in 2014.

Overcoming these problems, the government as a regulator has implemented several policies, such as implementation high tax of personal vehicle progressively for the owners who has car more than one, and so on. Besides, the government also provides massive transportation modes as alternative transportation. Currently, in Jakarta Transjakarta busway is available as one of public transportation choice. But, only few people are interested using Transjakarta.

Most people of DKI Jakarta prefer to use private vehicles then using public transportation. Using private vehicles is considered more practic and flexible and for security reasons also as the cause of the lack of public intention to choose public transportation. Beside that, most of users believe that using their own vehicle feels more comfortable.

However, increasing private vehicle usage causes many problems such as congestion, air pollution, lack of energy resources, and so on. This fact is very contrary with the values of moral responsibility and the principles of each individual. Abrahamse et al. (2009) in his research explained that personal norms are factors that affect the intention to reduce car use. Doran and Larsen (2016) in his research indicated that personal norms are the strongest factor related to behavioural intention in choosing environmentally friendly modes of transportation. Social factor 
DOI: 10.14807/ijmp.v10i1.748

can influence someone to select transportation mode. Each individual has different social environment level. $\mathrm{Ng}$ and Phuong (2015) explained that social influence is an important determinant of the public's intention in using public transportation.

Lack of public awareness to environmental impacts is also suspected to be a factor in the lack of public intention in using Transjakarta. Whereas Ernst (2005) explained that in the first month of Transjakarta operation, circulation of transportation modes from cars and motorcycles to Transjakarta buses in corridor I. It has reduced of NOx emissions level with value $212 \mathrm{~kg} /$ day and particles with aerodynamic diameters less than $10 \mathrm{~lm}$ (PM10) with $31 \mathrm{~kg} /$ day.

The quality impression experienced by consumers when using public transportation is also an important indicator of the behavioral intention of its users. The profit of the usage of Transjakarta is a comparison between the costs issued with perceived quality. Jen et al. (2010) argueded that perceived value is the most important indicator of intention behavior of public transport users. It can be said so because perceived costs affect the intention behavior of public transport users through perceived value of the mode of transportation. Similar to perceived costs, perceived quality is an important indicator in relation to the intention behavior of public transport.

Anything that related to issues of congestion, environmental pollution, inefficiency, and exploitation of the environment can be reduced if private vehicle users are willing to switch to public transportation mode. There is important research that examines the factors that affect the intention to use public transport, especially Transjakarta as the variables described above. For those reason, it is necessary to learn all the factors that influences, such as: personal norms, social influence, environmental impact, and perceived quality of public transport on the intention of using Transjakarta simultaneously. Examining the kind factors influence to the public intention of private vehicle users for using public transportation significantly. The model based on a conceptual framework is used as a basis in analyzing the relationship between variable that related with intention in using public transportation. 
DOI: 10.14807/ijmp.v10i1.748

\section{THEORETICAL FRAMEWORK}

\subsection{Intention to use behavior}

Consumer behavior is a consumer action in consuming goods, by spending a certain cost and get certain benefits from goods that consumption in such way that consumers achieve their goals. Peter and Olson (2010), states that the American Marketing Association defines consumer behavior as a dynamic interaction of feelings, cognitions, behaviors, and the environment in which individuals exchange in various aspects of their lives. Hawkins and Mothersbaugh (2013), states that consumer behavior is the study of how individuals, groups, and organizations process to choose, secure, use and discontinue products, services, experiences or ideas to satisfy their needs and impact on consumers and society.

Related to the definition described, there are several theories related to the consumer behavior. In this research, consumer behavior focuses on the behavior of transportation mode usage. To understand why commuters are choosing to drive in private vehicles instead of using eco-friendly public transport modes, it is necessary to observe at their behavior in choosing modes of transportation and their intention to use public transportation. Two approaches that often used to explain the proenvironment behavior are Theory of Planned Behavior (TPB) and The NormActivation Model (NAM) (BONNES; BONAIUTO, 2002). TPB proposed by Ajzen (1985) considers that pro-environment is the result of an individual cost-benefit analysis. While NAM assumes that moral considerations are based on proenvironment behavior.

Theory of Planned Behavior (TPB) is an extension of Theory of Reasoned Action (TRA). In TRA it is explained that one's intention toward behavior is formed by two main factors: attitude toward behavior and subjective norms (FISHBEIN; AJZEN, 1975), whereas in TPB is added one more factor that perceived behavioral control (AJZEN, 1991). There are 3 independent variables in TPB namely attitude, subjective norm, and perceived behavioral control. Attitude is factor in a person learned to give a positive or negative response to an assessment of something given. Subjective norm (subjective norm) is a person's perception about the thoughts of others who will support or not support him in doing something. Perceived behavioral control is the perception of ease or difficulty in performing a behavior. 


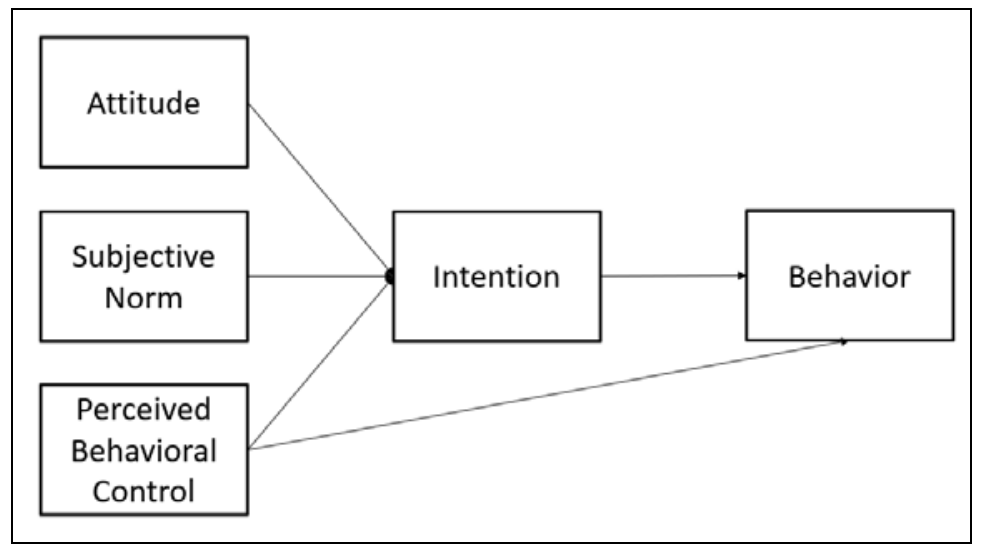

Figure 1: Theory of planned behaviour model (Ajzen 1991)

Schwartz (1977) originally developed NAM in the context of altruistic behavior in which personal norms form the core of this model. Schwartz (1977) states that these norms are actively experienced as a feeling of moral obligation rather than intention. These personal norms are used in NAM to predict individual behavior. The model states that these personal norms are determined by two factors: the realization that doing or not doing certain behaviors has certain consequences, and a sense of responsibility for performing specific behaviors (SCHWARTZ,1977).

Most studies interpret NAM as a model of mediator or moderation model. The mediator model shows that awareness of the consequences affects personal norms through ascribed responsibility. Moderation models show that the effect of personal norms on behavior is moderated by consciousness of consequences and ascribed responsibility. De Groot and Steg (2009) recently compared these two interpretations in five studies and provide strong evidence that NAM is a mediator model.

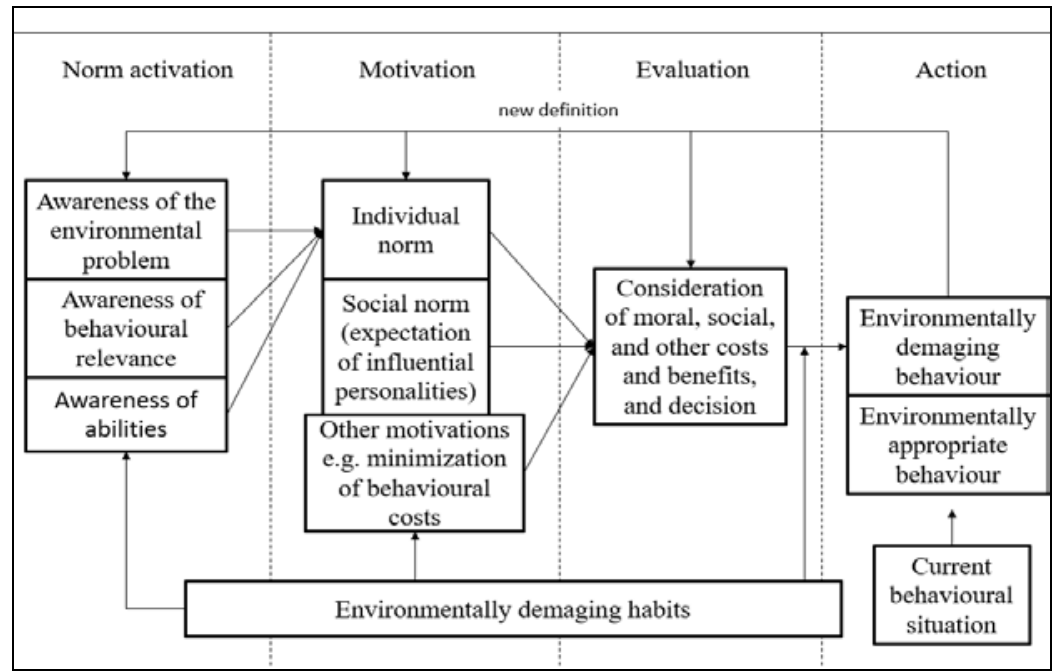

Figure 2: Norm-activation model (Schwartz 1977) 
Their findings indicate that one should be aware of the consequences of behavior before feeling responsible for it. Furthermore, De Groot and Steg (2009) say the feeling of responsibility activate personal norms, and personal norms causing individual behavior.

\subsection{Relationship between personal norms and intention to use public transport}

According to Harland et al. (2007) moral theory considers that proenvironment behavior as an option of moral situations when an individual's actions have consequences for the welfare of others. In contrast to rational choice theories, moral theory shows that pro-social behavior or pro-environmental behavior, influenced by feelings of moral obligation or personal norms. According to the normactivation model the intensity of personal obligation occurs when a person feels to take behavioral actions that affect the environment (SCHWARTZ, 1977).

Pro-environmental behavior can be considered as a form of altruistic behavior, because it requires the sacrifice from personal benefits for the sake of the environment. For example, in order to reduce the environmental problems caused by the use of private vehicles, we decided to go to work on the bus, which reduces some comforts because we must walking more to reach bus shelter, less freedom (less choice when to get home and working, to fit bus schedules), and may take longer travel time.

Fujii and Van (2009) on the results of his research indicate that moral concerns are the determinants of behavioral intention to use the bus. Sumaedi and Yarmen (2015) conducted a study about the effect of moral norm on the intention to use public transport in Bogor, Indonesia. The study used a quantitative method with a survey of 277 respondents.

The results of this study show that positive norm morality significantly influences the behavioral intention of public transport users. Zhang et al. (2015) conducted a study in Shanghai on social norms in the use of public transport. The results found that subjective social norms and internalized responsibility in using more environmentally friendly modes of transport stimulate intention to use public transport and increase the actual number of public transport users. 
Based on the theory of norm-activation model (NAM) and findings of some previous research, it is seen that there is a close relationship between personal norms and intention to use public transport. So this study also examines the influence of personal norms variable with the intention of private vehicle owners to use Transjakarta. Thus Hypothesis 1 in this research:

$\mathrm{H}_{1}$ :Personal norms affects intention to use Transjakarta significantly.

\subsection{Relationship between social influence and intention to use public transport}

Social factors are a group of people who consider about the equality in community status or awards that constantly socialize among themselves both formally and informally (KOTLER; ARMSTRONG, 2008). Rahmatsyah (2011) says that consumer beliefs can be influenced by the information they receive from the social environment. In theory of planned behavior (TPB), social influence is a subjective norm which is a belief that arising from the impulse of the view or social environmental assumptions. Ajzen and Fishbein (1980) say that subjective norms refer to the social pressure given to engage in certain behaviors.

In this study, social influence variable refers to the encouragement of important people such as family, friends, and colleagues to use Transjakarta. The higher social involvement, the higher impetus to use Transjakarta. This may affect a person's intention in using Transjakarta.

There are several previous studies that link social influence with intention to use public transport. $\mathrm{Ng}$ and Phuong (2015) conducted research on the interest of motorcycle users in Hanoi, Vietnam to use the bus. The study says that service satisfaction, personal belief, and social influence have a significant impact to the intention of road users to use public transportation. Research conducted Setiawan (2012) says that most often mentioned relating normative belief (normative belief) are parents, boyfriend, and friends.

Ambak et al. (2016) conducted a study of behavioral intention in using public transportation based on the Theory of Planned Behavior (TPB) model in Batu Pahat and Kluang, Malaysia. The results showed that attitude toward public transport is the most dominant factor when compared with subjective norm and perceived behavior 
DOI: 10.14807/ijmp.v10i1.748

control in influencing people to use bus. Most respondents agree that the use of buses is cheap and there is no better alternative mode of transportation.

Choocharukul and Fujii (2007) conducted an investigative study of psychological factors that could be a predictor of behavioral intention in the use of private vehicles for future work trips. The results of this study found that subjective norm, attitude, and moral obligation are significant determinants for behavioral intention. Tung and Kubota (2015) conducted a study related to treveler psychology motivation in choosing public transportation. The result of this research show that social awareness influence bus use intention. Zailani et al. (2016) found that social interaction associated with the use of buses did not affect people's interest in using buses.

Based on the theory of planned behavior (TPB) and two opposite research results from previous studies related to intention to use public transport, this study tried to test the influence of social influence variable with the intention of private vehicle owners to use Transjakarta. Thus Hypothesis 2 in this research:

$\mathrm{H}_{2}$ : Social influence affects intention to use Transjakarta significantly.

\subsection{Relationship between environment impact and intention to use public transport}

Environmental impact arising from the use of motor vehicles can be felt with real. Motor vehicles produce $\mathrm{CO} 2$ emissions that contribute to global warming (OECD, 2002). The use of private vehicles includes contributing to behavior that is not pro-environment. While one solution to resolve the environmental impact is reduce the use of private vehicles and switch to public transportation.

There are several studies that examine the relationship of environmental impact with intention to use public transport. $\mathrm{Ng}$ and Phuong (2015) in his research said that the world environment impact and local environmental impact has no significant relationship to consumer intention. Borhan et al. (2014) conducted research on the interest of using public transportation in Putrajaya, Malaysia.

This study was conducted with the aim to find out what factors affect the willingness of the public to use public transportation rather than using private vehicles. The results of this study indicate that service quality and attitude have a positive influence on the behavioral intention of the use of public transportation. In 
DOI: 10.14807/ijmp.v10i1.748

addition, service quality and environmental impact variables have a positive influence on attitude, but environmental impact does not affect the intention to use public transport.

The study by Osada et al. (2011) is about things that affect trevel intention by using parameters trevelers' personality and preference. Car preference and two types of personality, namely environmental concern and frugal lifestyle are selected as important factors that influence trevelers intention. The results of this study indicate that high level of car preference causes trevelers to choose a fast and massive trevel mode. Eco-friendly commuters have a high intention in eco-friendly modes of transport. Conventional public transport is the mode that becomes an option for commuters who have a higher frugal lifestyle.

The interest to refrain from using private vehicles is higher on eco-friendly commuters and frugal lifestyle. Personality and preference also affect the attitudes of commuters. Tung et al. (2015) conducted research on treveler behavior with proenvironmental approach. The results of this study indicate that there is no difference in mode-use obligation between private vehicle users who have environmental concerns with public transport users who have social and environmental concerns.

Haryanto and Purnomo (2016) conducted a study investigating the effects of environmental knowledge as moderating variables of re-use public transportation. The results show that trevel time efficiency affects the satisfaction and service value. Furthermore, satisfaction influences intention to re-use and environment knowledge moderates the relationship between satisfaction and intention to re-use public transportation.

Based on field facts from the environmental impacts and previous research, this research tries to test the influence of environment impact variable with the intention of private vehicle owner to use Transjakarta. Thus Hypothesis 3 in this research:

$\mathrm{H}_{3}$ : Environment impact affects intention to use Transjakarta significantly.

\subsection{Relationship between perceived quality and intention to use public transport}

The impression of perceived quality will determine the assessment of the product. Zeithaml (1988) says that the perceived value of a product is a trade-off 
DOI: 10.14807/ijmp.v10i1.748

between perceived benefit and perceived cost. As with transport services, passengers will use a particular transport service if passengers feel comfortable, secure, accessible, and so on by comparing prices or sacrifices. There are several studies that examine the perceived quality variables associated with intention to use public transport.

Sumaedi et al. (2012) in his research on public transportation proves that perceived value and service quality significantly influence the behavioral intention of passengers. The results also show that perceived value is significantly influenced by service quality and perceived sacrifice. The data used are taken from 339 passengers paratransit by using questionnaire method. Fujii and Van (2009) in the results of his research explain that quality perception influence behavioral intention to use the bus.

Jen and $\mathrm{Hu}$ (2003) conducted repurchase intention studies on public transport users. It is said that repurchase intention is influenced by perceived value. Jen et al. (2010) also said in his study that perceived value is the most important predictor of the satisfaction and behavioral intention of public transport users. Sukwadi and Theophilus (2015) conducted a study of Jabodetabek KRL users. The results show service quality has a positive impact on perceived value. Perceived value and passenger satisfaction have a positive impact on engagement. Service quality and engagement have a positive impact on behavioral intention.

Based on the explanation, this research tries to test the influence of perceived quality of public transport variable with the intention of private vehicle owner to use Transjakarta. Thus Hypothesis 4 in this research:

$\mathrm{H}_{4}$ : Perceived quality of public transport affects intention to use Transjakarta significantly.

\section{METHODOLOGY}

\subsection{Research approach}

This research was conducted by quantitative descriptive method by using survey, which was done by questionnaire to get the result factually, systematically, thoroughly, and accurately related to the characteristics and facts that exist in the field of research object. Survey approach is done by submitting a list of statements in 
DOI: 10.14807/ijmp.v10i1.748

the form of questionnaires to the respondents. The data collected in this research was conducted from March to May 2017 in Jabodetabek area.

Data collection was done by giving questionnaire. Questionnaires were given in two ways, online through google form and self-administered questionnaire printed to the respondents as many as 250 people. Likert scale 5 points is used to measure main variable.

\subsection{Research sampling}

Determination of the sample is done by purposive sampling that is intentional sampling in accordance with the sample criteria required in this study. Criteria of respondents include:

a. Male / female with age $>16$ years old.

b. Have a personal vehicle either motor or car.

c. Private vehicle users who have used Transjakarta to get an idea of respondents' perceptions about the quality of Transjakarta services.

Based on Roscoe (1975) and Hair et al. (2005) the number of samples in SEM is determined by the number of model coefficients to be expected, 5 - 10 times the number of coefficients. The number of variables in this study are 5 variables derived into 27 items. So based on the rules of thumb the number of samples to be used are between 135-270 samples.

\subsection{Research variables and measurement method}

In this research there are two variable, exogenous latent variables and endogenous latent variables. Latent variables used are based on concepts and studies from some previous research. All constructing items are measured using Likert indicating 5 points, 1 indicating strongly disagree, and 5 indicating strongly agree. Explanation of the operational definition of each variable can be seen in Table 1.

Table 1 : Definition and variable measurement

\begin{tabular}{|c|c|c|c|}
\hline $\begin{array}{l}\text { Latent } \\
\text { variables }\end{array}$ & Description of latent variables & Indicator variables & References \\
\hline \multirow{2}{*}{$\begin{array}{l}\text { Intention to } \\
\text { use } \\
\text { Transjakarta } \\
\text { (I) }\end{array}$} & \multirow{2}{*}{$\begin{array}{l}\text { The stage of individual } \\
\text { inclination to act before the } \\
\text { decision is actually } \\
\text { implemented, in this case the }\end{array}$} & Intention1 (Y1) & \multirow{2}{*}{$\begin{array}{l}\text { Ng dan } \\
\text { Phuong } \\
\text { (2015), Fujii } \\
\text { dan Van }\end{array}$} \\
\hline & & Intention2 (Y2) & \\
\hline
\end{tabular}


INDEPENDENT JOURNAL OF MANAGEMENT \& PRODUCTION (IJM\&P)

http://www.ijmp.jor.br

v. 10, n. 1, January - February 2019

ISSN: 2236-269X

DOI: 10.14807/ijmp.v10i1.748

\begin{tabular}{|c|c|c|c|}
\hline & intention in using Transjakarta. & Intention3 (Y3) & $\begin{array}{l}\text { (2009), } \\
\text { Sumaedi et } \\
\text { al. (2012). }\end{array}$ \\
\hline \multirow{3}{*}{$\begin{array}{l}\text { Personal } \\
\text { norms (PN) }\end{array}$} & \multirow{3}{*}{$\begin{array}{l}\text { Individual beliefs, related to } \\
\text { moral principles and } \\
\text { responsibility for the use of } \\
\text { private vehicles. }\end{array}$} & Guilty feeling (X1) & \multirow{3}{*}{$\begin{array}{l}\text { Abrahamse et } \\
\text { al. (2014), } \\
\text { Doran dan } \\
\text { Larsen (2016) }\end{array}$} \\
\hline & & Responsibility (X2) & \\
\hline & & Personal principle (X3) & \\
\hline \multirow{5}{*}{$\begin{array}{l}\text { Social } \\
\text { influence (SI) }\end{array}$} & \multirow{5}{*}{$\begin{array}{l}\text { Things that affect consumers } \\
\text { in choosing a product derived } \\
\text { from the social environment of } \\
\text { the consumer. }\end{array}$} & Support influence (X4) & \multirow{5}{*}{$\begin{array}{l}\text { Ng dan } \\
\text { Phuong } \\
\text { (2015), } \\
\text { Setiawan } \\
\text { (2012). }\end{array}$} \\
\hline & & $\begin{array}{l}\text { Social encouragement } \\
\text { (X5) }\end{array}$ & \\
\hline & & Family influence (X6) & \\
\hline & & Coworker influence (X7) & \\
\hline & & Friend influence (X8) & \\
\hline \multirow{6}{*}{$\begin{array}{l}\text { Environment } \\
\text { impact (EI) }\end{array}$} & \multirow{6}{*}{$\begin{array}{l}\text { Negative impacts caused by } \\
\text { the use of motor vehicles, } \\
\text { which cause environmental } \\
\text { damage and environmental } \\
\text { situations and roads are not } \\
\text { conducive. }\end{array}$} & Noise pollution (X9) & \multirow{6}{*}{$\begin{array}{l}\text { Ng dan } \\
\text { Phuong } \\
\text { (2015), Fujii } \\
\text { dan Van } \\
\text { (2009). }\end{array}$} \\
\hline & & Energy crisis (X10) & \\
\hline & & Air pollution (X11) & \\
\hline & & Road congestion (X12) & \\
\hline & & Social exclusion (X13) & \\
\hline & & Traffic safety (X14) & \\
\hline \multirow{10}{*}{$\begin{array}{l}\text { Perceived } \\
\text { quality of } \\
\text { Transjakarta } \\
\text { (PQ) }\end{array}$} & \multirow{10}{*}{$\begin{array}{l}\text { The impression of quality on a } \\
\text { product received by } \\
\text { consumers after using a } \\
\text { product, which can shape } \\
\text { consumer perceptions of the } \\
\text { product. }\end{array}$} & Comfort (X15) & \multirow{10}{*}{$\begin{array}{l}\text { Fujii dan Van } \\
\text { (2009), Jen } \\
\text { et.al. (2010), } \\
\text { Borhan et. al. } \\
\text { (2014) }\end{array}$} \\
\hline & & Accessibilty (X16) & \\
\hline & & Speed (X17) & \\
\hline & & Punctuality (X18) & \\
\hline & & Security (X19) & \\
\hline & & Money_cost (X20) & \\
\hline & & Courtesy (X21) & \\
\hline & & Route (X22) & \\
\hline & & Schedule (X23) & \\
\hline & & Convinience (X24) & \\
\hline
\end{tabular}

\subsection{Data analysis}

The model used in this study is predictive relationship modeling and Structural Equation Modelling (SEM) technique is used to test the hypothesis using LISREL 8.72.software.

\section{RESULT AND DISCUSSION}

\subsection{Demographics and respondents' behavior}

Factors influencing consumer intention in using Transjakarta are the variables analyzed as well as the objectives in this research, so to achieve these objectives in addition to supported by some previous research, this study used the required respondents. Demographics of respondents can be seen in Table 2. From 190 
DOI: 10.14807/ijmp.v10i1.748

people, most respondents are male, undergraduate, 19 - 28 years old and private employee.

Table 2 : Respondents' demograpichs

\begin{tabular}{|c|c|c|c|}
\hline Demographics & Parameter & Frequent & $\begin{array}{l}\text { Persentage } \\
(\%)\end{array}$ \\
\hline \multirow{9}{*}{ Domicile } & Jakarta Barat & 13 & 6.84 \\
\hline & Jakarta Pusat & 9 & 4.74 \\
\hline & Jakarta Selatan & 19 & 10.00 \\
\hline & Jakarta Timur & 29 & 15.26 \\
\hline & Jakarta Utara & 8 & 4.21 \\
\hline & Bekasi & 53 & 27.89 \\
\hline & Bogor & 28 & 14.74 \\
\hline & Depok & 16 & 8.42 \\
\hline & Tangerang & 15 & 7.89 \\
\hline \multirow{2}{*}{ Gender } & Male & 109 & 57.37 \\
\hline & Female & 81 & 42.63 \\
\hline \multirow{5}{*}{ Education } & Primary school & 26 & 13.68 \\
\hline & $\begin{array}{l}\text { Diploma } \\
\text { D1/D2/D3/D4 }\end{array}$ & 15 & 7.89 \\
\hline & $\begin{array}{l}\text { Bachelore degree } \\
\text { (S1) }\end{array}$ & 128 & 67.37 \\
\hline & Master (S2) & 19 & 10.00 \\
\hline & Doctor (S3) & 2 & 1.05 \\
\hline \multirow{5}{*}{ Age } & $19-28$ year & 121 & 63.68 \\
\hline & $29-38$ year & 51 & 26.84 \\
\hline & $39-48$ year & 9 & 4.74 \\
\hline & $49-58$ year & 8 & 4.21 \\
\hline & $59-68$ year & 1 & 0.53 \\
\hline \multirow{7}{*}{ Employment } & Privat & 108 & 56.84 \\
\hline & BUMN & 24 & 12.63 \\
\hline & Enterpreneur & 12 & 6.32 \\
\hline & $\begin{array}{l}\text { Government } \\
\text { employee }\end{array}$ & 6 & 3.16 \\
\hline & Student & 15 & 7.89 \\
\hline & Housewife & 10 & 5.26 \\
\hline & Etc. & 15 & 7.89 \\
\hline
\end{tabular}

In the selection of transportation mode, respondent rarely choose public transportation for daily trevel. There are $80 \%$ of respondents owning motorcycles and $64 \%$ owning cars. The results showed $69 \%$ of respondents admitted rarely use public transportation in one month. While those who claim to often use public transportation in one month only $31 \%$.

For experience in using public transport other than Transjakarta, 49\% of respondents have used city bus, $73 \%$ taxi, $62 \%$ city transport, $82 \%$ online motorbike taxis, $70 \%$ Commuterline and other public transportation by $22 \%$. Over the last few 
DOI: 10.14807/ijmp.v10i1.748

months the transportation costs incurred by each respondent vary greatly from the lowest of 50,000 rupiahs to the highest of $3,000,000$ rupiah.

\subsection{Goodness of fit research model}

The structural equation of SEM output with LISREL 8.72 software can be seen in Figure 7. Chi-square value $\left(X^{2}\right)=354.70$ with degrees of freedom $(\mathrm{dF})=305$. If chi-square is compared with degrees of freedom $\left(X^{2} / d F\right)$ then the ratio $=1.16$. This ratio is still acceptable because the ratio value is $<3.00$. Thus it can be concluded that the model has a good fit to the data collected.

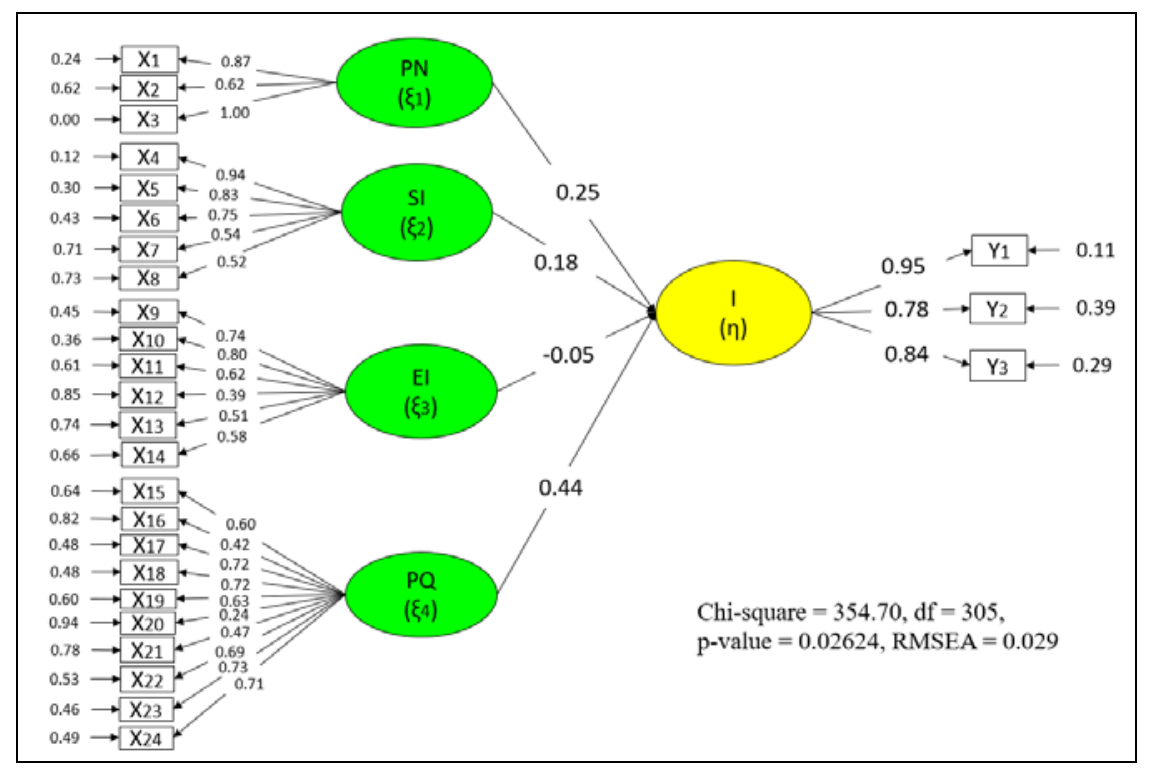

Figure 3: standardize loading factor value in the framework of research model

The next test is goodness of fit of model test which approach by criteria of SEM using goodness of fit (GOF) cut-off. Table 3 shows that the RMSEA criterion yields a value of $0.029 \leq 0.08$ which means that the resulting model is good fit.

Table 3: GOF of overall research model

\begin{tabular}{|l|c|c|c|}
\hline \multicolumn{1}{|c|}{ Goodness-of-Fit } & Cut-off-Value & Hasil & keterangan \\
\hline p-value & $\geq 0.05$ & 0.026 & Poor Fit \\
\hline RMR (Root Mean Square Residual) & $\leq 0.05$ atau $\leq 0.1$ & 0.071 & Good Fit \\
\hline $\begin{array}{l}\text { RMSEA (Root Mean Square Error } \\
\text { of Approximation) }\end{array}$ & $\leq 0.08$ & 0.029 & Good Fit \\
\hline GFI (Goodness of Fit) & $\geq 0.90$ & 0.96 & Good Fit \\
\hline CFI (Comparative Fit Index) & $\geq 0.90$ & 1 & Good Fit \\
\hline Normed Fit Index (NFI) & $\geq 0.90$ & 1 & Good Fit \\
\hline $\begin{array}{l}\text { Adjusted Goodness of Fit Index } \\
\text { (AGFI) }\end{array}$ & $\geq 0.90$ & 0.95 & Good Fit \\
\hline Relative Fit Index (RFI) & $\geq 0.90$ & 1 & Good Fit \\
\hline R-squared ( $\left.\mathrm{R}^{2}\right)$ & $\geq 0.50$ & 0.53 & Good \\
\hline
\end{tabular}


Other goodness of fit criteria indicate by CFI, NFI, AGFI, and RFI value that > 0.90 which means the model is good fit. Likewise with the criteria of other goodness of fit measurements RMR value 0.1, which means good fit model. This shows that the several criteria resulted in the conclusion of goodness of fit model which means the research model has been able to be used in doing the assessment or measuring the observed variable, so that the hypothesis testing theory can be done.

\subsection{Path coefficient indicator analysis}

Each variable has several indicators that become the benchmark of the variable. Table 4 shows the value of loading factor in personal norms variable. The loading factor value of three indicators is more than 0.5 , this means personal norms variable described well by the three indicators. X3 has the largest loading factor value where X3 is a reflection of one's personal principle to use Transjakarta. It can be said that the personal principle of someone in using Transjakarta is the biggest indicator in describing the variable of personal norms.

Table 4: loading factor of personal norm

\begin{tabular}{|c|l|r|}
\hline $\begin{array}{c}\text { Variabel } \\
\text { Indikator }\end{array}$ & \multicolumn{1}{|c|}{ Item } & $\begin{array}{c}\text { Loading } \\
\text { Factor }\end{array}$ \\
\hline$X_{1}$ & Guilty feeling & 0.87 \\
\hline$X_{2}$ & Responsibility & 0.62 \\
\hline$X_{3}$ & Personal principle & 1 \\
\hline
\end{tabular}

Table 5 shows value of social influence loading factor. Loading factor value of the five indicators is more than 0.5 , this means the three indicators describe the personal norms well. $X 4, X 5, X 6$ has the greatest loading factor value which indicates the effect that arises from the people who are considered important in the life of respondents to use Transjakarta. So it can be said that encouragement to use Transjakarta from the people who are considered important or the people closest is the greatest indicator in describing the variable of social influence.

Table 5: Loading factor of social influence

\begin{tabular}{|c|l|r|}
\hline Variabel Indikator & \multicolumn{1}{|c|}{ Item } & Loading Factor \\
\hline$X_{4}$ & Support influence & 0.94 \\
\hline$X_{5}$ & Social encouragement & 0.83 \\
\hline$X_{6}$ & Family influence & 0.75 \\
\hline$X_{7}$ & Coworker influence & 0.54 \\
\hline$X_{8}$ & Friend influence & 0.52 \\
\hline
\end{tabular}


Table 6 shows the value of environment impact loading factor. Loading factor value of the five indicators is more than 0.5 , this means five indicators describe the environment impact well. Unlike X12 item, its loading factor value is below 0.5 , but the item statement is important that states directly about congestion problems, so $\mathrm{X} 12$ is still used as one of the indicators. X10 has the largest loading factor value which indicates the depletion of energy source due to car or motorcycle usage. This means that the problem of energy resource depletion is the most depicting environmental impact.

Tabel 6: Loading factor of environment impact
\begin{tabular}{|c|l|r|}
\hline $\begin{array}{c}\text { Variabel } \\
\text { Indikator }\end{array}$ & \multicolumn{1}{|c|}{ Item } & $\begin{array}{c}\text { Loading } \\
\text { Factor }\end{array}$ \\
\hline $\mathrm{X}_{9}$ & Noise pollution & 0.74 \\
\hline $\mathrm{X}_{10}$ & Energy crisis & 0.8 \\
\hline $\mathrm{X}_{11}$ & Air pollution & 0.62 \\
\hline $\mathrm{X}_{12}$ & Road congestion & 0.39 \\
\hline $\mathrm{X}_{13}$ & Social exclusion & 0.51 \\
\hline $\mathrm{X}_{14}$ & Traffic safety & 0.58 \\
\hline
\end{tabular}

Table 7 shows the value of perceived quality loading factor. Seen on items $\mathrm{X} 16, \mathrm{X} 20, \mathrm{X} 21$ have values less than 0.5 , this means accessibility items, money_cost, and courtesy less describe perceived quality variables. However, this item still used because these three items are important indicators to describe the quality of service, where these three items are also used in research of Sumaedi et al. (2012), Jen and $\mathrm{Hu}$ (2003), Borhan et al. (2014) and several other studies. The value of other loading factor is more than 0.5, this means that the indicator represents the perceived quality well. X23 has the largest loading factor value which indicates the schedule of Transjakarta operations. This means that Transjakarta's operational schedule is the most important indicator in describing perceived quality variables.

Tabel 7: Loading factor of perceived quality of Transjakarta

\begin{tabular}{|c|l|r|}
\hline $\begin{array}{c}\text { Variabel } \\
\text { Indikator }\end{array}$ & \multicolumn{1}{|c|}{ Item } & $\begin{array}{r}\text { Loading } \\
\text { Factor }\end{array}$ \\
\hline $\mathrm{X}_{15}$ & Comfort & 0.6 \\
\hline $\mathrm{X}_{16}$ & Accessibilty & 0.42 \\
\hline $\mathrm{X}_{17}$ & Speed & 0.72 \\
\hline $\mathrm{X}_{18}$ & Punctuality & 0.72 \\
\hline $\mathrm{X}_{19}$ & Security & 0.63 \\
\hline $\mathrm{X}_{20}$ & Money_cost & 0.24 \\
\hline
\end{tabular}


DOI: 10.14807/ijmp.v10i1.748

\begin{tabular}{|l|l|r|}
\hline$X_{21}$ & Courtesy & 0.47 \\
\hline$X_{22}$ & Route & 0.69 \\
\hline$X_{23}$ & Schedule & 0.73 \\
\hline$X_{24}$ & Convinience & 0.71 \\
\hline
\end{tabular}

Table 8 shows the value of intention to use Transjakarta loading factor. Loading factor value of the three indicators is more than 0.5 , this means that the three indicators describe intention to use Transjakarta well. The largest loading factor value is $\mathrm{Y} 1$ where this indicator does not include the element of time and the seriousness of interest, so it is broader in general. So $\mathrm{Y} 1$ is most powerful item that represents the intention to use Transjakarta variables.

Tabel 8: Loading factor of intention to use Transjakarta

\begin{tabular}{|c|l|r|}
\hline $\begin{array}{c}\text { Variabel } \\
\text { Indikator }\end{array}$ & \multicolumn{1}{|c|}{ Item } & $\begin{array}{c}\text { Loading } \\
\text { Factor }\end{array}$ \\
\hline $\mathrm{Y}_{1}$ & Intention1 & 0.95 \\
\hline $\mathrm{Y}_{2}$ & Intention2 & 0.78 \\
\hline $\mathrm{Y}_{3}$ & Intention3 & 0.84 \\
\hline
\end{tabular}

\subsection{Hypothesis testing}

Hypothesis testing on research model using SEM, done by evaluating path coefficient and $t$ value of each variable in research conceptual model. The test results of each path in two variables yielded $t$ values that describe the significance of two tested variables. Testing the hypothesis as presented in Table 9.

Table 9: result of hypothesis testing

\begin{tabular}{|c|c|c|c|c|}
\hline Hypothesis & Path & Path Coefficient & $t$ value & Results \\
\hline $\mathrm{H}_{1}$ & $\mathrm{PN} \rightarrow \mathrm{I}$ & 0.25 & 4.60 & Accepted \\
\hline $\mathrm{H}_{2}$ & $\mathrm{SI} \rightarrow \mathrm{I}$ & 0.18 & 3.21 & Accepted \\
\hline $\mathrm{H}_{3}$ & $\mathrm{EI} \rightarrow \mathrm{I}$ & -0.05 & -1.31 & Rejected \\
\hline $\mathrm{H}_{4}$ & $\mathrm{PQ} \rightarrow \mathrm{I}$ & 0.44 & 6.89 & Accepted \\
\hline \multicolumn{2}{|l|}{$\mathrm{R}$-squared $\left(\mathrm{R}^{2}\right)=0.53$} & & Good \\
\hline
\end{tabular}

$*) \mid \mathrm{t}$ value $\mid>1.96 \rightarrow$ Significant

The relationship between personal norms (PN) and intention to use Transjakarta (I) resulted in a significant t-value so that hypothesis $\mathrm{H} 1$ which states that the personal norms of consumers affect the intention to use public transport is acceptable. It can be concluded that personal norms are one of the factors influencing user intention in using Transjakarta. This is an indicator that basically the beliefs of principle and moral responsibility for the impact of using private vehicles affect the public intention in choosing Transjakarta as a daily transportation mode. 
This is in line with researches by Abrahamse et al. (2009), Fujii and Van (2009), Doran and Larsen (2016), Zailani et al. (2016), and Borhan et al. (2014). In Fuji and Van's research (2009) personal norms are described as moral concerns associated with the respondent's belief in the environmental impact. These findings illustrate that contributing to use the bus can reduce air pollution and traffic congestion, and this can happen if the respondent understands that there is a need for real action to switch using the bus.

In the second hypothesis that states the social influence (SI) affects intention to use Transjakarta (I) produce significant t-value. Thus the hypothesis $\mathrm{H} 2$ is acceptable. It can be concluded that social influence is one of the factors influencing user intention in using Transjakarta.

This is in line with researches by $\mathrm{Ng}$ and Phuong's (2015) and Setiawan (2012). The influence of family, coworkers, schoolmates, and people who become the social environment of respondents has an important role in influencing the intention of respondents in choosing the mode of transportation. Social influences can also be attributed to the personal beliefs of the public.

It needs special encouragement to general public and education in increasing the belief about the importance and advantages of using Transjakarta. If public beliefs in the use of buses increases, it can create more social influence. However, unlike Fujii and Van (2009) and Zailani et al. (2016) who said that social interaction associated with the use of buses does not reduce the public intention to use the bus.

Furthermore, it show in table 9, the relationship between environmental impact (EI) on intention to use Transjakarta (I) yields t-value is not significant, so H3 which states that environment impact affecting intention to use public transport can be rejected. It can be concluded that the environmental impact caused by the use of private vehicles is not a factor influencing user intention in choosing Transjakarta as transportation mode.

This is in line with the findings of $\mathrm{Ng}$ and Phuong (2015) and Borhan et al. (2014). Ng and Phuong (2015) say that the people of Hanoi are not motivated to use the bus even though they live in an polluted environment caused by private vehicles. While Borhan et al. (2014) in his research found that environmental impact does not affect the behavioral intention directly, but indirectly influence through attitude 
DOI: 10.14807/ijmp.v10i1.748

variables. In contrast to Fujii and Van (2009) who conducted research in Ho Chi Minh City said that the environmental impact of using private vehicles became a moral concern that affected the intention in using buses significantly. The results of this study are likely to occur due to lack of awareness and education of Jabodetabek people regarding the depletion of energy sources, air pollution, congestion, and other environmental impacts due to the use of private vehicles.

The last hypothesis test is to test the relationship between perceived quality of Transjakarta (PQ) against intention to use public transport (I). Table 9 shows that the $\mathrm{t}$-value is statistically significant, so the hypothesis $\mathrm{H} 4$ which states that Perceived quality of public transport influences the intention to use public transport is acceptable. Thus it can be concluded that consumer perceptions of Transjakarta quality is one of the factors that influence consumer interest in choosing Transjakarta as a transportation mode.

These findings are in line with many previous studies such as Sumaedi et al. (2012), Fujii and Van (2009), Jen and Hu (2003), Jen et al. (2010), and several other studies. Consumer perceptions in transportation quality is the most significant factor that affects the intention in using Transjakarta. This can be seen from the highest tvalue compared to other variables $6.89>1.96$. The better public perception of Transjakarta service quality, the higher intention to use it, the worse public perception on the quality of service, the lower intention to use it. Jen and Hu (2003) also found that if user have a good perceptions of service value, they will tend to reuse it.

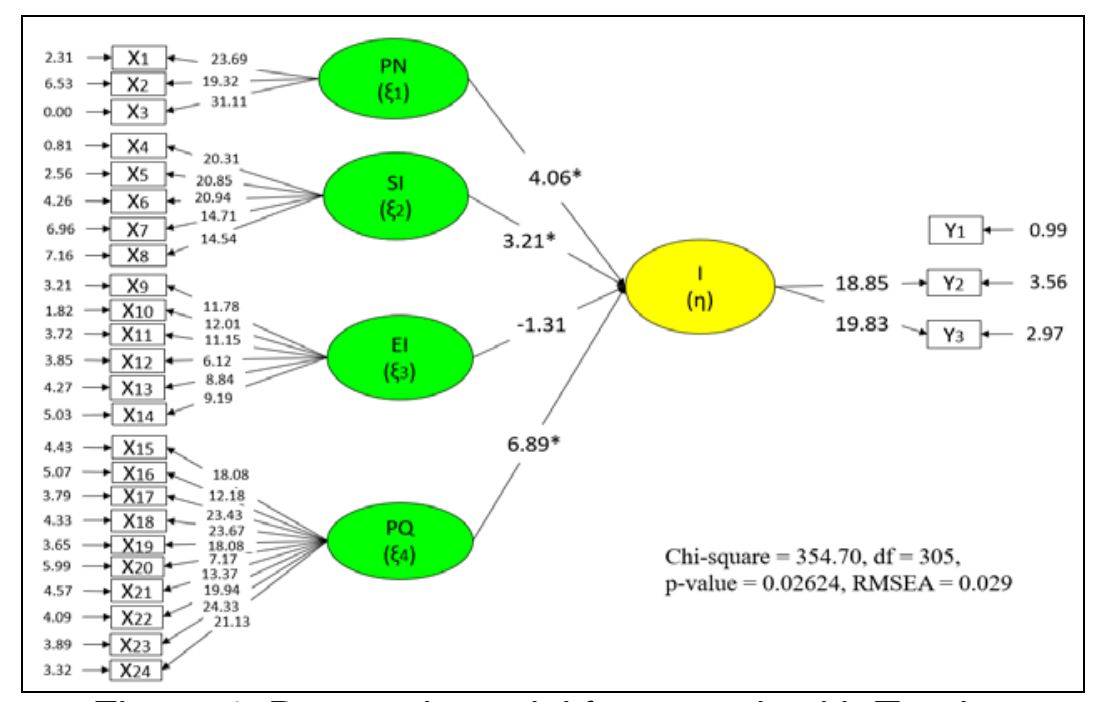

Figure 4: Research model framework with T-value 
The value of R-squared in this research model can be categorized well, it yields 0.53 , this means the intention to use Transjakarta variable is influenced by independent latent variable by $53 \%$ in this research model. While $47 \%$ is influenced by other independent variables.

\section{CONCLUSION}

PT Transjakarta is currently continuing its development by adding fleets and operational routes. This will be very effective if balanced with the increasing intention of people to use Transjakarta. This study attempts to describe the interests of private vehicle user behavior and analyze the factors that influence their interest in using Transjakarta.

The study found that respondents who own private vehicles rarely choose to use public transport. The survey shows that the respondents' intention in using Transjakarta buses is quite low. Intention to use Transjakarta is influenced by several variables, that is personal norms, social influence, and perceived quality public transport. Meanwhile, environment impact variable does not affect intention to use public transport. Perceived quality is the most variable that significantly influences intention to use public transport when compared with other three variables. In perceived quality variables, item with scores below 50 percent are related to speed, timeliness, operational schedule, and number of routes from Transjakarta.

\section{IMPLICATION AND RESEARCH LIMITATION}

Through this research is expected to provide benefits and images for stakeholders, especially the government and PT Transjakarta to be one of the basic considerations in terms of increasing public intention in using public transportation. To achieve this, the government as regulator and PT Transjakarta as service provider can consider the findings of this research by choosing a strategy to create urgency of public transportation usage, in particular Transjakarta as a transportation mode choice for the community. The managerial implication in this research is done by STP approach (segmentation, targeting, positioning) and 4P (product, price, place, promotion).

Transjakarta has a wide market segmentation, male or female, from the young to the old, the economy up to the bottom, students or workers, and others. Related to 
DOI: 10.14807/ijmp.v10i1.748

this research, it can be seen that private vehicle owners have weak intention towards Transjakarta, then PT Transjakarta can do targeting to Jabodetabek people who are private vehicle users as potential consumers. Furthermore, to get the positioning in the minds of consumers, the government and PT Transjakarta need to broadcast about Transjakarta's advantages and access to open information related to services Transjakarta. Furthermore related to the findings in this study, more details are elaborated with $4 \mathrm{P}$ on each variable.

The Government and PT Transjakarta can make several efforts to increase public awareness related to the use of Transjakarta, in terms of product, price, place, and promotion. In terms of product, the government and PT Transjakarta can socialize the urgency to switch using Transjakarta, as well as education about Transjakarta services. Create an attractive bus display design and design that puts the user's comfort. improve Transjakarta services especially in terms of speed and timeliness, routes, and schedules. In relation to speed and timeliness, PT Transjakarta must seek to increase the sterilization of Transjakarta's special lanes from other vehicles that are not necessarily entering the bus lanes, so the bus does not experience any obstacles. PT Transjakarta can also add routes to expand operational coverage. While related to the schedule, distance and span of time between buses with one another is shortened so that the passenger waiting time is shorter. Besides that, the application of smartphone-based can be apply to be able to infiltrate the location of the nearest stop, and monitor the bus in realtime, and also passengers can provide suggestions and reports of complaints through the application.

In terms of price, the current implementation is quite affordable for all segment. In relation to place, socialization can be done at hangouts such as malls, cafes, restaurants, and places of daily activities such as schools, universities and offices. Can also involve the campus environment and academic community, as well as hobby community. Implementation in improving services is done in all areas of Transjakarta operations. For smartphone applications accessible on all platforms of any smartphone OS.

In terms of promotion PT Transjakarta can give free electronic money to potential user as promotion which is used as means of payment in using Transjakarta, and promote the superiority of Transjakarta services at this time. 
DOI: 10.14807/ijmp.v10i1.748

Publicize public service announcements, seminars and campaigns on Transjakarta through all communication media. Promo via digital on smartphone can also be done to maximize the dissemination of information. Giving trip discounts or even purchasing vouchers for app users. Finally, inform about the change of services in terms of improving the quality of service through all media.

This study has limitation that need to be developed later in the future. This research does not measure the performance factor of Transjakarta. As well as busy routes, as well as hours that become operational busy times. In addition, this study does not consider certain routes that buses are rare, making Transjakarta users long to wait.

Suggestions submitted by the authors for further research on public transportation, especially Transjakarta is by considering a research model that enriches the literature so the study can use variables more widely. Using a combination of grand theory like Theory Planned Behavior (TPB) and Normactivation Model (NAM) or other grand theory as a whole. Incorporating other variables that affect intention to use public transport such as personality traits and personal dilemma by Abraham and Wirayudha (2015), travel time and satisfaction by Haryanto and Purnomo (2016), and also compares the intention between private vehicle users and public transport users such as research conducted by Osada et al. (2011).

\section{REFERENCES}

ABRAHAM, J.; WIRAYUDHA, M. S. (2015) Personality traits, sedentariness, and personal dilemma as the dynamic predictors of intention to use public transportation in greater Jakarta. Makara Hubs-Asia, v. 19, n. 2, p. 125-143. DOI 10.7454/mssh.v19i2.3481.

ABRAHAMSE, W.; STEG, L.; GIFFORD, R.; VLEK, C. (2009) Factors influencing car use for commuting and the intention to reduce it: A question of self-interest or morality?. Transportation Research Part F, v. 12, p. 317-324.

\section{AJZEN, I.; FISHBEIN, M. (1980) Understanding Attitudes and Predicting Social}

Behavior. New Jersey, US: Prentice-Hall.

AMBAK, K.; KASVAR, K. K.; DANIEL, B. D.; PRASETIJO, J.; GHANI, A. R. A. (2016) Behavioral intention to use public transport based on theory of planned behavior. MATEC Web of Conferences, n. 47(03008), p. 1-7. DOI: 10.1051/matecconf/20164703008. 
INDEPENDENT JOURNAL OF MANAGEMENT \& PRODUCTION (IJM\&P)

http://www.ijmp.jor.br

v. 10, n. 1, January - February 2019

ISSN: 2236-269X

DOI: 10.14807/ijmp.v10i1.748

BONNES, M.; BONAIUTO, M. (2002) Environmental Psychology: From Spatial Physical Environment to Sustainable Development, Handbook of Environmental Psychology. New York, US: John Wiley and Sons, Inc.

BORHAN, M. N.; SYAMSUNUR, D.; AKHIR, N. M.; YAZID, M. R. M.; ISMAIL, A.; RAHMAT, R. A. (2014) Predicting the use of public transportation: a case study from Putrajaya, Malaysia. The Scientific World Journal, v. 2014, n. 784145, p. 1-9. DOI 10.1155/2014/784145.

CHOOCHARUKUL, K.; FUJII, S. (2007) Psychological factors influencing behavioral intention of private car use in future work trips. Proceeding of The Eastern Asia Society for Transportation Studies, v. 6, n. 2007, p. 1-12.

DORAN, R.; LARSEN, S. (2016) The relative importance of social and personal norms in explaining intentions to choose eco-friendly travel options. International Journal of Tourism Research, v. 2016, n. 18, p. 159-166. DOI 10.1002/jtr.2042.

ERNST, J. P. (2005) Initiating bus rapid transit in Jakarta, Indonesia. Journal of Transportation Research Board, v. 3, n. 103, p. 20-26.

FUJII, S.; VAN, H. T. (2010) Psyschological determinants of the intention to use the bus in Ho Chi Minh city. Journal of public Transportation, v. 12, n. 1, p. 97-110.

HAIR, J. F. J.; ANDERSON, R. E.; TATHAM, R. L.; BLACK, W. C. (2005) Multivariate Data Analysis. 6th ed. New Jersey, US: Prentice Hall.

HARYANTO; PURNOMO, $\mathrm{H}$. (2016) The effect of moderating variable of environment knowledge on the intention to re-use of public transportation. Proceeding of International Conference on Climate Change. [Internet]. [Waktu dan tempat pertemuan tidak diketahui] Surakarta, ID: JFPUNS, p . 52-58.

HAWKINS, D. I.; MOTHERSBAUGH, D. L. (2013) Consumer Behaviour: Building Marketing Strategy. New York, US: McGraw-Hill Higher Education.

JEN, W.; HU, K. C. (2003) Aplication of perceived value model to identify factors affecting passengers repurchase intentions on city bus: a case of the Taipei metropolitan area. Transportation Journal, v. 30, n. 3, p. 307-327.

JEN, W.; RUNGTING, T.; TIM, L. (2011) Managing passenger behavioral intention: an integrate framework for service quality, satisfaction, perceived, value and switching barriers. Transportation Journal, v. 38, p. 321-342. DOI 10.1007/s11116010-9306-9.

KOTLER, P.; ARMSTRONG, G. (2008) Prinsip-Prinsip Pemasaran. Ed ke-12. Jakarta, ID: Erlangga.

NG, P. Y.; PHUONG, P. T. (2015) From motor biking to public transportation what matters in Hanoi?. World Journal of Management, v. 6, n. 2, p. 1-15.

OSADA, C.; TANGPHAISANKUN, A.; OKAMURA, T.; NAKAMURA, F.; WANG, R. (2011) Influences of commuters' personality and preferences on travel intention in developing countries: a case of Bangkok. Proceedings of The Eastern Asia Society for Transportation Studies [Internet]. [Waktu dan tempat pertemuan tidak diketahui]. Yokohama, JP: JSTAGE, p. 370-381. [diunduh 2016 Aug 7]. Tersedia pada: https://www.jstage.jst.go.jp/article/easts/9/0/9 $0370 /$ pdf.

PETER, J. P.; OLSON, J. C. (2010) Consumer Behavior and Marketing Strategy. 9th ed. New York, US: McGraw-Hill Higher Education. 
DOI: 10.14807/ijmp.v10i1.748

RAHMATSYAH, D. (2011) Analisa faktor-faktor yang mempengaruhi minat pengguna produk baru (Studi Kasus: Uang Elektronik Kartu Flazz BCA).

Thesis. Jakarta, ID: Universitas Indonesia.

SCHWARTZ, S. H. (1977) Normative Influences on Altruism. In Berkowitz, L. Advances in Experimental Social Psychology. New York, US: Academic Press.

SETIAWAN, R. (2012) Keyakinan-keyakinan utama mahasiswa pengguna mobil ke kampus. Thesis. Surabaya, ID: Universitas Kristen Petra.

SUMAEDI, S.; BAKTI, I. G. M. Y.; YARMEN, M. (2012) The impact study of public transport passengers behavioral intentions: the roles of service quality. Perceived sacrifice, perceived value, and satisvaction (case study: paratransit passengers in Jakarta, Indonesia). International Journal for Traffic and Transport Enginerring, v. 2, n. 1, p. 83-97.

SUMAEDI, S.; YARMEN, M. (2015) The effect of moral norm on public transport passengers' behavioral intention (case study: public transport passengers in Bogor, Indonesia). Transport Problems, v. 10, n. 4, p. 15-23.

SUKWADI, R.; TEOFILUS, G. (2015) Behavioral intention penumpang KRL commuter line Jabodetabek. Jurnal Teknik Industri, v. 10, n. 2, p. 71-76.

TUNG, N. H.; KOJIMA, A.; KUBOTA, H. (2015) Impacts of travellers' social awareness on the intention of bus usage. International Association of Traffic and Safety Sciences, v. 39, n. 3, p. 130-137. DOI 10.1016/j.iatssr.2015.03.001.

TUNG, N. H.; KUBOTA, H. (2015) Psycological motivation of travelers' behavior regarding the use of public transportation. Research Report of Department of Civil and Environmental Engineering, v. 41, n. 2, p. 12-23.

ZAILANI, S.; IRANMANESH, M.; MASRON, T.A.; CHAN, T. H. (2016) Is the intention to use public transport for different travel purpose determined by different factors?. Transportation Research Part D, v. 49, n. 3, p. 18-24. 